\title{
Eurooppalaista oppimisulottuvuutta rakentamassa
}

Kuhn, Michael \& Sultana, Ronald G. (eds. 2006). Homo Sapiens Europaeus? Creating the European Learning Citizen. New York: Peter Lang.

Mistä on eurooppalaiset oppivat kansalaiset tehty? Vapaaehtoisuudesta ja mielekkyydestä, elämän- ja työtilanteesta riippumattomista itsensä ja ympäristönsä kehittäjistä vaiko sittenkin taloudellisen kilpailukyvyn edistämiseksi valjastetuista koulutus- ja työllisyyspolitiikan objekteista? EU:n rahoittaman EURONE\&T verkoston tuella kootussa, Michael Kuhnin ja Ronald G. Sultanan toimittamassa artikkelikokoelmassa joukko eurooppalaisia ja muutama australialainenkin tutkija pohtii eurooppalaisen oppivan kansalaisen ideaalityypin herättämiä mielikuvia eri konteksteissa. Yhdeksi merkittäväksi seikaksi kirjoittavat nostavat kysymyksen koulutuksesta työllisyyden ja työllistettävyyden välineenä, jolloin oppiminen sen eri muodoissaan nähdään ennemminkin kilpailukykyisen EU:n rakentajana kuin yksilöiden etuoikeutena. Elinikäisestä oppimisesta tulee pakko, jota sovelletaan erityisesti formaalisti epäpätevien kouluttamiseen aktiivisiksi, yhteiskuntakelpoisiksi kansalaisiksi.

European Employment Strategy (ESS), Lifelong Learning (LLL) ja National Action Plan (NAP) ovat joitakin niistä EU:n koulutus- ja työllisyyspolitiikan strategioita, joita artikkeleissa käydään läpi. Tämä tekee- 
kin kirjasta hyödyllisen niille, jotka haluavat laajentaa ymmärrystään EU:n käyttämistä määritelmistä, strategioista ja niiden kansallisista sovelluksista koulutus- ja työllisyyspolitiikassa. Samalla lukija tulee tutuksi retoriikkaan liittyvien englanninkielestä johdettujen akronyymien kanssa, joita kirjan sivuilla käytetään paikoin ahkerasti.

Yhteensä 13 artikkelia sisältävä teos käsittelee EU-kansalaisuutta ja elinikäistä oppimista peilaten niitä muun muassa Iso-Britannian anglo-amerikkalaisen taustaan (Dale \& Robertson), tanskalaiseen oppimisen sosiaalista ja persoonallista puolta painottavaan traditioon (Rasmussen) sekä osanakansallisen ja ylikansallisen identiteetinmuodostuksen hallintaa (Field ja Murphy).

Viimeksi mainitussa artikkelissa todetaan elinikäinen oppiminen hallinnallisesti haasteelliseksi, koska elämänlaajuiset oppimismahdollisuudet eivät rajoitu perinteisten instituutioiden ja toimialajaottelujen mukaan. Eri organisaatioiden sisäinen toimintakulttuuri, aikataulukäsitykset sekä erilaiset suhteet valtioon monimutkaistavat yhteistyön suunnittelua ja koordinointia. Todellisen hallinnallisen yhteistyön sijasta voidaan tällöin toimia monen intressin sekamelskana, jossa myös käsitykset elinikäisen oppimisen implementoinnista vaihtelevat. Toisaalta Field ja Murphy muistuttavat EU:n pyrkimyksistä edistää yhteneviä käsityksiä ja identiteetinmuodostusta elinikäisen oppimisen saralla erilaisten viitekehyksien ja vaihto-ohjelmien avulla. Lopputulokseltaan he kuitenkin jäävät pessimistisiksi EU:n mahdollisuuksista voittaa eheän post- nationalistisen identiteetin muodostumisen tiellä olevat kulttuurilliset, hallinnalliset ja byrokraattiset esteet.

\section{Eurooppalainen basaari}

Magalhães ja Stoer yrittävät auttaa lukijoita ymmärtämään eurooppalaisuutta luomalla mielikuvan moniulotteisesta, mutta samojen lakien mukaan toimivasta basaarista. Tässä kielikuvassa kansalliset identiteetit tunnustetaan, mutta samalla integroidaan demokraattisessa neuvottelussa keskenään. Valta ja vaikuttaminen eivät tapahdu vain ylhäältä alas, vaan poliittiseen päätöksentekoon osallistuminen on mahdollista kaikille erilaisten informaalien ja formaalien verkostojen välityksellä sekä ylikansallisten yhteisten huolenaiheiden tiimoilta. Toisaalta osallistuminen globaaleihin verkostoihin edellyttää aktiivisuutta, kielitaitoa ja kulttuurien välistä kommunikointitaitoa sekä kykyä hyödyntää verkostoja. Näitä taitoja ei kaikilla ole ja siksi basaarin hulinassa voi toisten kojuissa käydä suurempi kuhina kuin toisissa - tuotteen laadusta riippumatta.

Magalhães ja Stoer korostavat eurooppalaisen kansalaisuuden rakentumista tiedon, informaation ja kompetenssien varaan. Tästä syystä kouluinstituution paikka ihmisten arjessa kansallisvaltiossa olennaisten kompetenssien ja tiedon välittäjänä on muuttunut "glokaalien" verkostojen ja nykyteknologian mahdollistaman tiedonkulun myötä. Kansalaiset voivat määritellä itsensä joustavasti tavalla, joka ei ole modernin ajan tavoin sidoksissa homogenisoiviin markkinavoimiin.
Koulujen haasteiksi aktiivisten EU-kansalaisten kasvattamiseen tämän artikkelin pohjalta voisi sanoa olevan basaarin periaatteisiin opastamisen lisäksi se, mitä sisäinen yrittäjyys voisi tässä kontekstissa tarkoittaa.

\section{Oppiminen ei ole globalisoitunut}

Lasken artikkelissa käydään euro-basaarin ulkopuolella: Japanin ja USA:n oppimisen ja koulutuksen välistä suhdetta tarkastellaan omina malleinaan Saksan edustaessayhtä eurooppalaista ammatillisen kasvatuksen traditiota, jossa painottuvat niin sosiaalinen kuin ekonominen kansalaisuus. Kulttuurisen kontekstin ja historian todetaan muokkaavan kasvatuksen, koulutuksen ja yhteiskunnan välisiä määrittelyjä sekä hallintamekanismeja. Lasken mukaan oppiminen ei ole siten globalisoitunut, vaan eri kulttuureissa on omat viitekehyksensä hahmottaa oppimista ja siihen liitettyjä merkityksiä. Tämä olisikin hyvä pitää mielessä avoimen koordinaation vertailu- ja indikaattoripolitiikassa ennen liian hätäisiä johtopäätöksiä.

Kirjan otsikkoon kansalaisesta viitataan artikkeleissa eri konteksteissa tarkoittaen muun muassa globaalin ja lokaalin välimaastossa olevaa toimijaa tai politikoinnin objekteja. Kymmenennessäluvussa(Seddon ja Mellor) avaa kansalaisuus-käsitettä (citizenship) hieman pidempään siirtymänä esimerkiksi syntyperän mukaisesta kuulumisesta ("belonging") tekemiseen ("do") velvoittamiseen. Tätä ja muita kansalaisen määrittelyjä, miksei problematisointiakin suhteessa EU retoriikkaan olisi kaivannut syväl- 
lisemmin läpi teoksen. Sen sijaan EU-kansalaisuutta määrittelevänä makrotekijänä nostetaan esille työllistettävyyteen, taloudelliseen kasvuun ja sosiaaliseen koheesioon kytkeytyvä elinikäinen koulutuspolitiikka Lissabonin strategian mukaisesti.

Työllisyys- ja koulutusstrategioiden kansallisia ja EU-tasoisia kehitysnäkymiä pohtivat erityisesti Stuart ja Greenwood (ESS), Keep (NAP), Odd Bjorn Ure (LLL) sekä Andy Green (LLL) artikkeleissaan. Suomi näyttäytyy näissä yhtenä mallimaana, jossa on riittävästi strategisia ja käytännön valmiuksia esimerkiksi sosiaalisten partnerien osalta ja eniten aikuiskoulutukseen osallistuvia. Samalla kuitenkin meillä olisi opittavaa heterogeenisemmista kansakunnista suvaitsevaisuudessa, kuten esimerkiksi Green (s. 250) toteaa.

Toisaalta osataan sitä muuallakin vierastaa ulkomaita: Ulma pyrkii artikkelissaan avartamaan ranskalaisten opettajiksi opiskelevien kapeaa katsantokantaa pohtimalla vaihto-ohjelmien mahdollisuuksia eurooppalaisen ulottuvuuden sisäistämisessä. Mikäli opettajat ymmärtävät vastuunsa aktiivisina eurooppalaisina kansalaisina, ovat myös heidän oppilaansa- kin todennäköisemmin tulevaisuuden konstruoijia tällä saralla. Samaa tuovat esille australialaisten esimerkkien kautta Seddon ja Mellor, jotka näkevät nuorten kasvattamisen kriittisiksi ajattelijoiksi ja demokraattisiksi kansalaisiksi olevan mahdollisuus monikulttuurisen Euroopan rakentumiselle.

Erinäisissä keskusteluissa on nostettu esiin huoli siitä, ovatko eurooppalaiset kiinnostuneita vaikuttamaan aktiivisesti EU -tasolla tai tietävätkö he ylipäätään oikeuksistaan ja mahdollisuuksistaan riittävästi ja jakautuuko kansalaiset pieneen poliittisesti aktiiviseen ja suureen passiiviseen joukkoon. Näitä teemoja ei tässä artikkelikokoelmassa kuitenkaan korosteta muutamia mainintoja enempää.

\section{Elinikäisen oppimisen ideologia kapeutunut}

Yhteinen huoli on ennen kaikkea elinikäisen oppimisen ideologian supistuminen taloudellisen hyödyn maksimoinniksi työllistettävyyden ja tehokkuuden kautta. Kauttaaltaan teos tuo hyvin esille sen, miten politiikkapaperien - miksei myös niihin kytkeytyvien tutkimusraporttien - yksinkertaistavat ylikansalliset ilmentyvät eivät ole noin vain implementoita- vissa käytäntöön, tai jos ovat, huolenaiheeksi nousee koulutuksen laadukkuuden ja monipuolisuuden säilyttäminen pelkän inhimillisen (tai taloudellisen) pääoman tuottamisen asemesta.

\section{Suomalaisuus}

\section{eurooppalaisuuden}

rakennusaineksena

Koska suomalaisena minua kiinnostaa, mitä muut meistä ajattelevat, luin artikkeleja myös tutkien Pohjoismaihin ja erityisesti Suomeen liitettyjä ilmaisuja ja tilastoja. Mielenkiintoisen lisän useissa artikkeleissa esiintyneeseen positiviseen (nyky)Suomikuvaan tuo kotimaisen Anja Heikkisen arvio historiallisesti perifeerisestä kansakunnasta Euroopan laidalla. Greenin tavoin voidaan kuitenkin pohtia, voisivatko Pohjoismaat toimia mallimaina muille jäsenmaille ja millä ehdoilla? Jotta eurooppalainen oppiva kansalainen ei olisi vain työllisyysobjekti, miten benchmarkata esimerkiksi elinikäistä koulutuksellista tasa-arvokulttuuria ja vapaan sivistystyön moninaisuutta sen tehokkaan "eurokelpoisen" kaventamisen sijaan?

\section{Hanna Laaksonen}

